\title{
Discursive Analysis of Tourism Advertisements
}

\author{
Ni Wayan Kasni ${ }^{1}$, I Wayan Budiarta ${ }^{2}$ \\ \{Wayankasni@gmail.com¹,Budy4rt476@gmail.com² ${ }^{2}$, \\ Master of Linguistics Study Program, Universitas Warmadewa, Denpasar-Bali, Indonesia
}

\begin{abstract}
Language serves an important part to transfer message on advertisement to the readers. The language used has its own features in order to be able to capture the readers' attention. Therefore this research was done in order to investigate three main problems on the tourism advertisement, namely (1) how is the features of the advertisements, (2) how is organization of the advertisements, (3) What is the purpose of the advertisement? The data used are qualitative data taken from hotel advertisements and restaurant advertisements. The data were analyzed by applying two main theories, namely the Theory of Critical Discourse Analysis by Fairclough (1989) and Van Djik (2002) .The result of the analysis revealed that the hotels advertisements use certain strategy of discourse in promoting the hotels. The strategy in the text covers the use of certain expressions, syntax, and stylistics which are all as boosters to drag the customers' intention. The hotel advertisements are arranged in a such attractive way that customers get vast information.
\end{abstract}

Keywords: Advertisement, Critical Discourse Analysis, discourse strategy.

\section{Introduction}

Tourism had influenced the growth on the country's economy sector in the world. According to World Tourism Organization, today, business on tourism or even surpasses other businesses, such as oil exports, food products, and automobiles. In Indonesia, tourism is one of the industry sectors which can increase the country income. According to The Minister Tourism of Indonesia, Arief Yahya, the country income targeted in 2019 is about USD 20 billion and in 2018 the target is about USD 17 billion. To achieve this target, the government has prepared three strategies, namely (1) marketing, (2) developing new destination, (3) preparing human resources. (https://ekbis.sindonews.com/read/1330952/34/menpar-targetkan-devisa-pariwisata-sebesar-

rp292-triliun-di-2019-1534420454). Dealing with developing new tourism destination, the government has run a program focused on 10 tourism destinations known as 10 New Bali. Those 10 destinations are Tanjung Kelayang in Belitung, Lake Toba in North Sumatera, Kepulauan Seribu in and Kuta Tua in Jakarta, Tanjung Lesung in Banten, Borobudur in Central Java, Mandalika in Lombok, Wakatobi in North Sulawesi, Labuan Bajo Komodo in Flores island, 
Morotai in North Maluku, dan Bromo Tengger Semeru in East Java (https://www.liputan6.com/lifesytle/read/3111919/kemenpar-tetapkan-top-3-prioritas-

pengembangan-10-bali-baru). Preparing the human resources on tourism sector can be done through trainings and education, whether it is through formal or informal programs,to prepare the reliable workers on tourism, while the marketing on tourism can be done through promotion on many different medias, newspapers, magazines, televisions, radios, and internet.

Nowadays advertising is very popular in promotion. One of its forms is advertising through internet or online advertising. It can be done on the Facebook, instagram, and website. The model advertisement through internet is very effective and efficient as the advertisement can be read by all of the readers all over the world. They just search the data needed on the website and they will be bombarded by a lot of information. Accordingly Lund et al ( 2017) argued that the global population is now use online social networks in social media where they share experiences and stories and consequently influence each other's perceptions and buying behavior. It is inline with the research done by Ertugan (2017) which reveals that Facebook advertisement is effectual in forming relation among customers as well as making a bond between customers and sellers. In addition, Alalwan (2018) reported that the intention of the customers in purchasing is influenced by some factors, such as performance expectation, hedonistics motivation, interaction, communicativeness, and finding relevancy.

Tourism advertising is one of the forms of advertising found on the website. On this advertisement the tourists are bombarded with a lot of information dealing with tourism, for example hotel advertisements. If we search the hotel advertisements on the website, there will be a lot of information about hotels, such as name of hotels, hotel rooms, hotel facilities, locations, and even guest reviews. The hotel advertisement is a form of discourse. Conceptually, Djik (1985) discourse is a communicative phenomenon, which is of procedural characters, occurs in a certain out-of-lingual context and is fixed in a speech as a formal structure-text (written or oral). As a discourse, tourism advertisements are shaped by language. Salim \& Hanita (2012), while Byun \& Jang (2015) suggested that the language is effective and cognitive based on phrases and expressions used can be observed in its emotional and rational contexts.

Hotel advertisements in Bali are also composed by language which carries their own characteristics to cope with the tourists' interest to buy the products or services offered. The language carries certain messages to the tourist. Some studies on tourism advertisements are those investigated by Avraham et al (2012), Ely( 2013), Gali et al (2016), ) and Valdez et al 2017), and Malenkinaa \& Ivanova (2018). Avraham et al (2012) argued that the narrative is important on promotion and the greatest element among the marketing means. The study done by Ely (2013) argued that a trustworthy advertising can assist to share the values and behavior. It can create realistic expectation and as the result the visitors will be satisfied with their trips. Gali et al (2016) suggested that the slogans are simple and have exlusive attractiveness as the result of the effectiveness of the message components, while Valdez et al (2017) reported that the supreme matters, such as action and things show the real delinealition potentially, while watchword denoting general concept related to the prospective visitors are resemiotized if picture is attached to produce the memes and Malenkina et al (2018) revealed that the Spanish website use copious persuasive language. Based on the studies mentioned above, it can be concluded that they have not investigated the hotel advertisemement yet. Besides, those studies have not observed the advertisements from the lexical features and the syntactic features. The data used were also not the 
tourism advertisements in the area known as cultural tourism. Therefore this study is focused on discursive strategy which is seen from the text, process, and social analysis of tourism advertisement in Bali. This research is recommended to give contribution to the tourism promotion strategy in Bali.

\section{Method}

The current study is categorized as qualitative research in which the phenomena and the events were explained elaboratively to determine the microstructures of online tourism advertisements in Bali. The data were taken from the advertisement of the 10 best hotels in Bali. Those 10 foremost places for spending the night in Bali were based on the categorization made by Bali by hotels.com provided on the http://www.bali-indonesia.com/top10-hotels.htm in which the range of score of the guests review living there are between 8-10. Additionally, all of them are 5 star hotels. The hotels are (1) Chedi Club Tanah Gajah, Ubud, (2)The Viceroy Bali, Ubud, (3) St.Regis.Bali Resort,Nusa Dua, (4) Kayumanis Jimbaran, (5) Legian Bali, (6) The Ungasan Clifftop Resort, (7) Jamahal Private Resort and Spa, (8) Katamama Seminyak, (9) Plataran Menjangan Resort and Spa, and (10) Maya Sanur Resort and Spa. They are all 5 star hotels in Bali. The data were then analyzed by using the theory of Cricital Discourse Analysis proposed by Fairclough (2001). The analysis is only focused on three aspects on the advertising discourse, namely (1) the textual analysis, process analysis , and social analysis.

\section{Result and Discussion}

Viewing the textual aspects of the 10 best hotels advertisements in Bali, it is found that they are constructed by three elements, namely (1) semantic, (2) syntax, and, (3) stylistics.

Table 1. The local meaning

\begin{tabular}{ll}
\hline The emphasis of local meaning & expressions \\
\hline Unique place & "Set in a rare and dramatic location" \\
\hline Luxury place & "Luxurious villa accommodation"
\end{tabular}

\begin{tabular}{ll}
\hline Nice beaches & "Gorgeous beach front" \\
\hline Convenience room & "Three 160sqm one-bedroom spa villas offer \\
& more convenience to spa-goers with daily 90- \\
minute complimentary spa treatments in a \\
private treatment room" \\
\hline "The five-star resort makes good use of its \\
natural surroundings, perched on a verdant \\
valley overlooking one of the legendary rivers \\
\hline
\end{tabular}




\begin{tabular}{ll}
\hline & in Bali". \\
\hline Hotel location & "The resort is a 90-minute transfer from the \\
& Ngurah Rai International Airport in southern \\
& Bali" \\
\hline Excellent facilities & "Its collection of suites, villas, and excellent \\
& restaurants \\
\hline Excellent service & "Full spa service, childcare, airport shuttle, free \\
& full breakfast, free area suttle" \\
\hline
\end{tabular}

Table 2. Syntax

\begin{tabular}{ll}
\hline Kinds of sentences & Sentences \\
\hline Declarative & "The five-star resort makes good use of its \\
& natural surroundings, perched on a verdant \\
& valley overlooking one of the legendary rivers \\
& in Bali." \\
\hline Imperative & "Book this hotels and collects nights after your \\
& stay" \\
\hline Incomplete & "Getting around" \\
\hline Interrogative & "Is the description of this hotel not correct?" \\
\hline
\end{tabular}

Table 3. Stylistics

\begin{tabular}{ll}
\hline Kinds & \\
\hline Hyperbole & "The Chedi Club at Tanah Gajah is set in a rare \\
& $\begin{array}{l}\text { and dramatic location in the scenic village of } \\
\text { Tengkulak, } \\
\text { Viceroy Bali presents luxurious villa } \\
\text { accommodation in the cool upland and cultural } \\
\text { heartland of Bali, Ubud" }\end{array}$ \\
\hline Weasal words & "Uniquely designed, well-trained buttler" \\
\hline Potency & "These villas are romantic and perfectly suit \\
& $\begin{array}{l}\text { honeymooners, who find a specially prepared } \\
\text { flower bath upon arrival plus sweet fruit, dipped }\end{array}$ \\
& in chocolate fondue" \\
\hline Familiar word & "You" \\
\hline Simple vocabulary & "See more, free breakfast" \\
\hline
\end{tabular}

Critical discourse analysis (CDA) was introduced in the 1980s by Norman Fairclough, Ruth Wodak, Teun van Djik, and others ( Blommaert and Bulcaen, 2000, p.447). Fairclough proposed three dimensional model in discourse analysis,namely (1) text analysis, (2) process analysis, and (3) social analysis. The model is presented in the figure 1. 


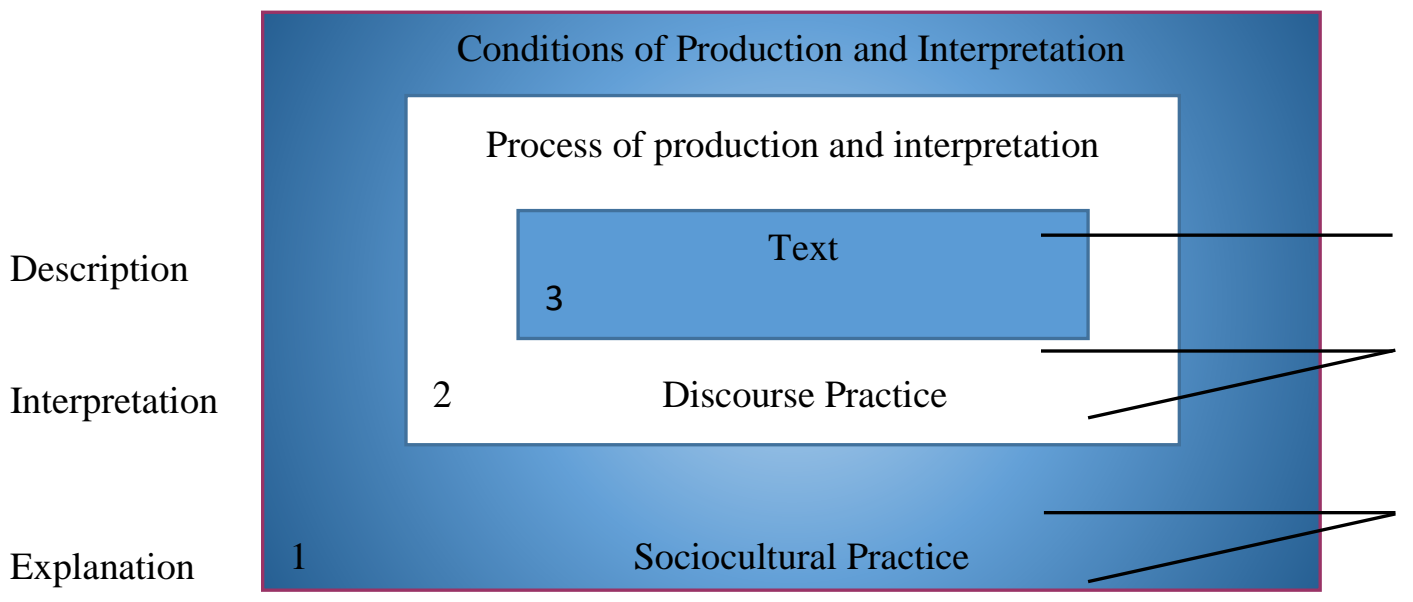

Figure 1. Production and Interpretation

Referring to this concept, the result of those three dimensions are as follows.

\subsection{Text Analysis}

The text of tourism advertisements in Bali are built by three elements, namely (1) semantic, syntax, and stylistic. The semantic element is corresponding with the local meaning, that is the meaning projected by the words composed in the form of sentences or proposition. Iedema (2003) explains that as a strategy on discourse, resemiotization is a way how meaning could shift from situation to situation, from use to use, or from one step of application to the next. (p.41). The advertisements convey 8 (eight) focused local meaning in term of the hotels promoted, namely (1) unique place,(2) luxury place,(3) niece beaches, (4) convenience rooms, (5) natural environment, (6) hotel location, (7) excellent facilities, (8) excellent service. From the syntax, the sentences used are categorized as imperative, declarative, interrogative, and incomplete sentences. The declarative sentences are started by the subject referring to the name of the hotel, the hotels location, the types of hotel room, the view, and hotel facilities. The imperative sentences are started with the verbs referring to the activities requested done by the tourists, while the interrogative is a kind of sentence asking for further suggestion from the tourists. The incomplete sentences are those appear without subject and verb but they are meaningful. The texts are also composed by some strategies in term with the stylistics, namely (1) hyperbole, (2) weasel word, (3) potential words, 
(4), familiar word, (5) simple vocabularies. The hyperbole in the advertisements are marked by the use of exaggerating words, such as dramatic, heartland, luxurious, vast, romantic. Weasel words are those suggesting a meaning without actually being specific. They are virtually, uniquely, welltrained. Familiar word is dealing with the use of pronoun you in order to show friendly relation to the customers. Simple vocabularies are used in the advertisements to convey easy understanding to customers.

\subsection{Processing Analysis}

The 10 best hotels of tourism advertisements in Bali are started with paragraphs giving the overview of the hotels. The overview consists of features of the hotels, their environments, view, distance, hotel facilities, and hotel services. The explanations are supported by pictures corresponding with the characteristics of the hotel. The advertisers in this case present some pictures to catch to the customers 'attention as illustrated in the following pictures.

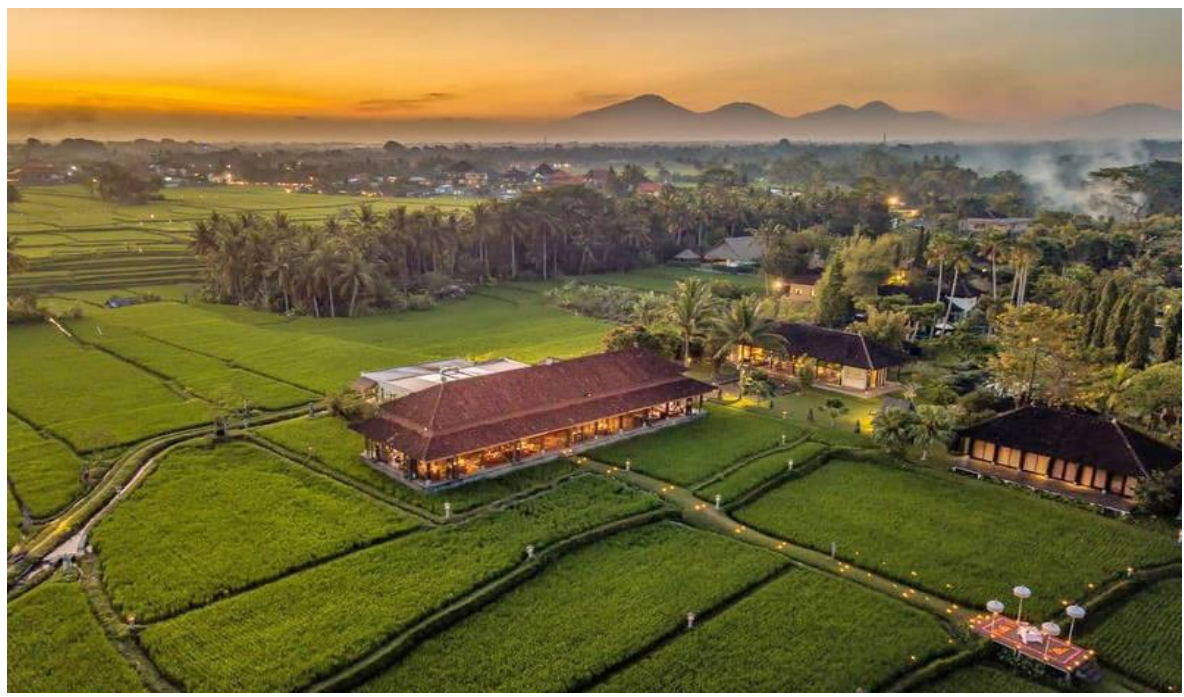

This picture has a close relationship with the verbal element of the advertisement as illustrated in the text below.

"The five-star resort makes good use of its natural surroundings, perched on a verdant valley looking one of the legendary rivers in Bali. Guests are welcome to the calm and serenity of the hotel grounds, and enjoy a stay that is close to nature and away from the hubbubs of modern life".

Beside the paragraph about the hotels strengths, the advertisement are also other forms verbal elements which are built in phrases and incomplete sentences. The phrases are mostly noun 
phrases describing the types of room, facilities, transports, and policies. The incomplete sentences are to ask the guests responses. All are also supported by the pictures related with the phrases used.

\subsection{The social analysis}

The 10 best hotels advertisements could be stated promotion implementing powerful linguistics units and images to sell places to stay for high class of tourists. Rabbiosi [11] argued that place marking is actually heightened and put into action using material, discursive and personified stagings that have the benefit in encouraging quick response and reinterpreting of shopkeepers and visitors, and other kinds of onlookers.

By describing the top features of the hotels and the excellent facilities and services, the hotels are worthy to be sold in high price. The strategy applied can be termed as persuasive strategy aiming at influencing the targeted tourist. It is supported by the research finding of [4] that revealed that the use of verbal messages is intended to affect attitudes and behavior of the customers or tourists. The relation of the language used and the customers target is illustrated below.

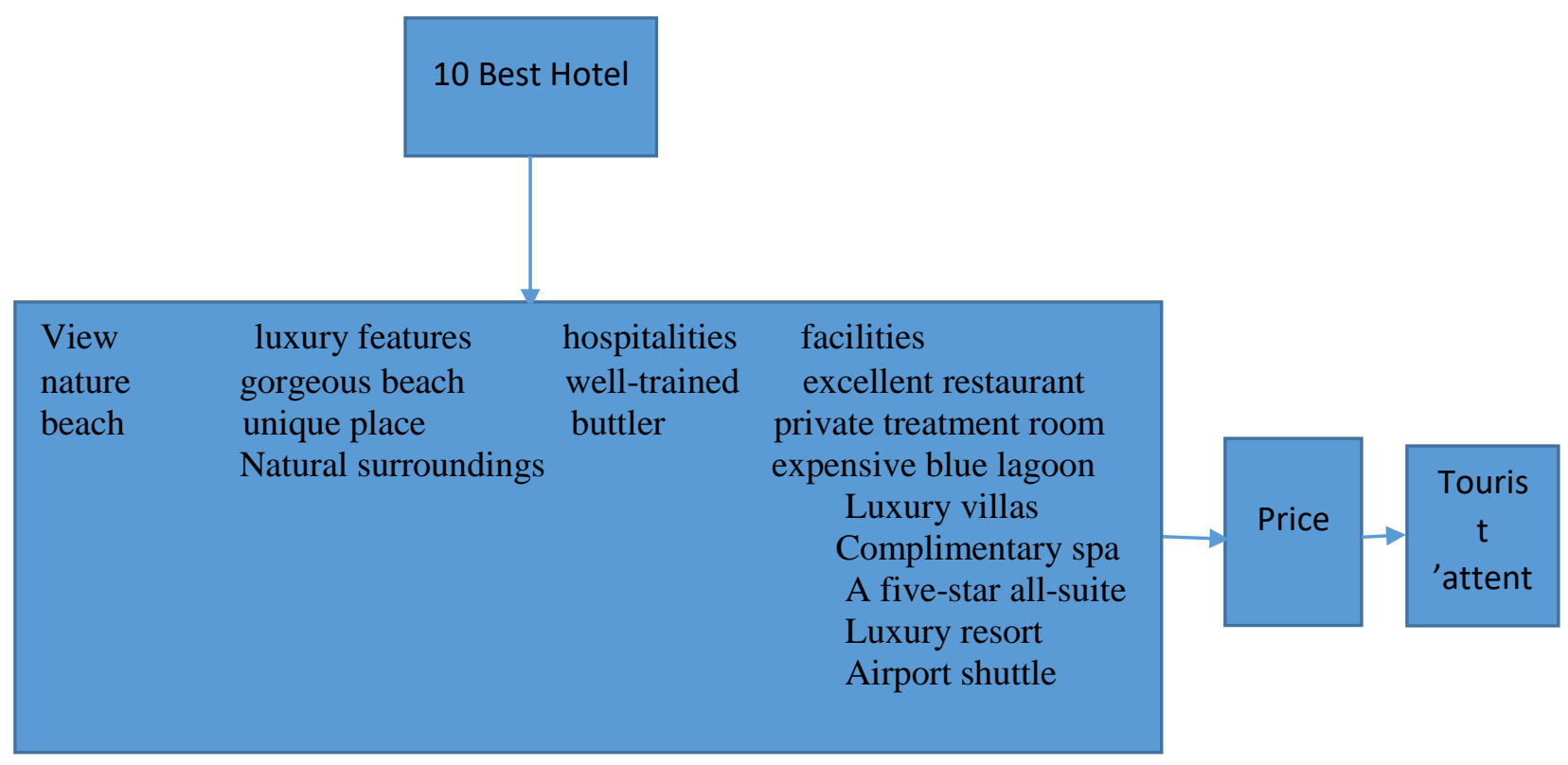

Figure 2. Relation Customers 


\section{Conclusion}

The 10 best hotels advertisements in Bali employed specific discursive strategy in promoting their products and services. The strategy involve the use of specific vocabularies which include the use of adjectives carrying high impact on the customers, the use noun or noun phrases referring to the high quality of hotel facilities, and the use of verbs implying the response of the customers. The advertisements are wrapped in certain forms using the certain spaces as available on the website to spoil the customers with a lot of information. The information is organized in the form of sentences and phrases and supported by pictures. In short, the use of the language on the 10 best hotels are targeted on selling the product or the services of the hotel to the high class of customers.

\section{Acknowledgement}

The authors express the greatest gratitude to the organizing committee of the International Conference on Social Sciences (ICOSS) of Universitas Warmadewa for the great contribution that has been granted to the launching of this scientific script at EAI Publisher. Hopefully the ideas found in the paper can be additional to the theoretical and practical konwledge for many parties.

\section{References}

[1] N. F. Lund, S. A. Cohen, and C. Scarles, "The power of social media storytelling in destination branding," J. Destin. Mark. Manag., 2017.

[2] A. Ertugan, "Using statistical reasoning techniques to describe the relationship between Facebook advertising effectiveness and benefits gained," Proscedia Comput. Sci., vol. 120, pp. 132-139, 2017.

[3] A. A. Alalwan, "Investigating the impact of social media advertising features on customer purchase intention," Int. J. Inf. Manage., vol. 42, pp. 65-77, 2018.

[4] M. A. Bin Salim, N. A. B. Ibrahim, and H. Hanita, "Language for Tourism: A Review of Literature," Procedia - Soc. Behav. Sci., no. 66, pp. 136-143, 2012.

[5] J. Byun and S. C. Jang, "Effective destination advertising: Matching effect between advertising language and destination type," Tour. Manag., vol. 50, pp. 31-40, 2015.

[6] E. Avraham and D. Daugherty, “' Step into the Real Texas': A s s o c i a t i n g a n d c l a i $\mathrm{m}$ i n g s t a t e n a r ra t ive in advertising and tourism brochu res," Tour. Manag., vol. 33, pp. 1385-1397, 2012.

[7] P. A. Ely, "Selling Mexico: Marketing and tourism values访," Tour. Manag. Perspect., vol. 8, pp. 80-89, 2013.

[8] N. Galí and R. C. J. A. Donaire, "Analysing tourism slogans in top tourism destinations," J. Destin. Mark. Manag., 2016.

[9] P. N. M. Valdez, R. Tupas, and N. C. Tan, “"'It's more fun in the Philippines": Resemiotizing and commodifying the local in tourism discourse," Discourse, Context Media, vol. 20, pp. 134-145, 2017.

[10] N. Malenkinaa and S. Ivanova, "A linguistic analysis of the official tourism websites of the seventeen Spanish Autonomous Communities," J. Destin. Mark. Manag., 2018.

[11] C. Rabbiosi, "Place branding performances in tourist local food shops," Ann. Tour. Res., vol. 60, pp. 154-168, 2016. 